\title{
Virtual Learning Environments in the Light of the Complexity Paradigm: Interface, Affordances and Equifinality
}

\author{
Ambientes virtuais de aprendizagem à luz \\ do Paradigma da Complexidade: Interface, \\ Affordances e Equifinalidade
}

Valeska Virginia Soares Souza*

Universidade Federal de Uberlândia

Uberlândia - Minas Gerais/Brasil

\begin{abstract}
I have investigated, through the lens of the Complexity Paradigm, aligned with the premises of the Theory of General Systems and the concept of affordances, two virtual learning environments (VLEs), defining them as systems composed of digital genres, regarding a VLE as a complex adaptive system. These VLEs were reconfigured from the platforms TelEduc and Moodle and used to teach the discipline "Digital Literacy", in the course of Languages and Literature Teaching degree at the Federal University of Minas Gerais (UFMG), during the second semester of 2007 and the second semester of 2008, respectively. The analyses have indicated that the textual production of the emerging online discourse communities was influenced by the coupling of different layers of the interface, the textual genres and the communicative and pedagogical purposes and, also, by the affordances which were perceived and acted upon by teachers and learners. The analyzed VLEs have portrayed the characteristic of equifinality, regardless of the possibilities and constraints offered by the platforms TelEduc and Moodle.
\end{abstract}

KEYWORDS: Virtual learning environments; Complexity Paradigm; Distance learning.

RESUMO: Investigo, através da lente do Paradigma da Complexidade, juntamente com os pressupostos da Teoria Geral dos Sistemas e do conceito de affordances, dois ambientes virtuais de aprendizagem (AVAs), definindo-os como sistemas compostos por gêneros digitais, partindo do pressuposto de que um AVA é um sistema adaptativo complexo. Esses AVAs foram reconfigurados a partir das plataformas TelEduc e Moodle e utilizados para ministrar a disciplina "Letramento Digital", no curso de Letras da Universidade Federal de Minas Gerais (UFMG),

*valeska_souzaefap@yahoo.com 
nos semestres 2007-2 e 2008-2, respectivamente. As análises indicam que a produção textual das comunidades discursivas on-line emergentes nos AVAs foi influenciada pelo acoplamento aninhado de camadas distintas da interface, dos gêneros textuais e dos propósitos comunicativos e pedagógicos, e, ainda, pelas affordances percebidas e efetivadas por professoras e aprendizes. Os AVAs analisados apresentaram a característica de equifinalidade, independentemente das possibilidades e restriçóes oferecidas pelas plataformas TelEduc e Moodle.

PALAVRAS-CHAVE: Ambientes virtuais de aprendizagem; Paradigma da Complexidade; Educação a distância.

\section{Introduction}

In the words of Ludwig Wittgenstein, "language is part of our organism and no less complicated than it". ${ }^{1}$ I could understand how appropriate Wittgenstein's quote was when I conducted my doctorate research. I believe the author was alluding to the complexity of language and this was evident in the investigation I will refer to in this article. The general goal of my research was to analyze the virtual learning environment (henceforth VLE) as a complex adaptive system composed of digital genres. My interest was to comprehend the dynamicity and the process of adaptability in the textual production in a VLE during the activities of a Distance Education academic course.

In this paper, I propose to discuss the characteristics of the VLE interface, i.e. the environment as a set of technical configurations composed of tools in which texts are posted. I explain how participants perceive and act upon the affordances of the environment: the possibilities which are available are utilized due to the users' needs. This agency leads to the equifinality of systems - if we are to compare the two VLEs analyzed (TelEduc and Moodle).

\section{Theoretical Framework}

The Complexity Paradigm is concerned with the behavior of dynamic systems, particularly, those that change with time, and proposes a holistic view of such systems. Dynamic or complex systems are self-organizing and adaptive, since they search to take advantage of whatever surrounds them, not only reacting passively to it; therefore, in these systems, it is possible to learn from every experience (WALDROP, 1992). Although primarily developed for the Exact Sciences, the Education area, including Applied Linguistics, have

${ }^{1}$ Available at: <http://en.wikiquote.org/wiki/Ludwig_Wittgenstein>. 
been benefiting from the Complex Paradigm as an alternative to research implementation due to its non-reductionist and nonlinear approach, based on the complex thought (DAVIS; SUMARA, 2006).

Johnson (2003) bases his explanation of how to understand systems by dividing them into three camps, as proposed by Weaver (1948). Simple systems include those consisting of very few variables. A simple system usually mentioned in Physics textbooks is a simple billiard table, with balls colliding with each other, according to simple rules: their speed, the friction with the table. A second camp would comprise disorganized complexity, or complicated systems, problems of millions of variables that can only be approached by the methods of statistical mechanics or probability theory. He exemplifies it with a very large billiard table with millions of balls rolling in different directions, colliding with each other and with the walls. Even though the path of a single ball may be erratic, or even unknown, the system itself has measurable average properties.

Organized complexity, or complex systems, on the other hand, refers to a system with a sizeable number of factors that have correlated interactions, which produce emergent, all-encompassing properties. The example he gives is a motorized billiard table on which the balls follow specific rules and develop a distinct global behavior through their interactions, organizing themselves in a specific way or creating a specific pattern with time. This type of behavior, recurrent in nature, cannot be approached by statistical methods, since they involve simultaneous manipulation of factors that interrelate and form an organic whole.

According to Morin (1977), in 1931 Saussure added the concept of organization to systems, referring to them as organized wholes composed of elements dependent on other elements and on the whole. Adopting the perspective of elements, defined in relation to others by considering their place in this whole, Leite, Bornia and Coelho (2004), in the light of the General Systems Theory, refer to complicated systems as the ones which depict linear relationships of cause and effect where and whose causes and effects may be separated without endangering the system. Contrastingly, complex systems display dynamic interactions where relationships among parts cannot be discarded.

An organized complexity system is defined in the General Systems Theory by the existence of robust interactions or nonlinear interactions. The proponent of this theory, Bertalanffy (1975), claimed that the whole is greater than the sum of its parts in such a system. The author wrote about some important concepts for the Complexity Paradigm, such as, open systems, 
equifinality and adaptivity. In contrast to a closed system, in which the final state is unquestionably determined by the initial conditions, the open system remains in constant flow of input and output.

Equifinality is a feature of open systems and commands in which the final state may be reached even by starting from different initial conditions and different ways. Equifinality determines the trend towards a characteristic final state, beginning at different initial states and following different paths, based on the dynamic interaction in an open system which acquires a stable state. I illustrate this with two salespeople who achieve a goal of selling the same value in products. Variables such as choice of products and customer interactions were probably not the same during selling process.

We could associate the concept of equifinality to the idea of emergence in the perspective of Van Lier (2004, p. 81). According to the author, "emergence thus can have different trajectories, can come about in different ways". The author exemplifies his point of view with the fact that children develop a stable linguistic system, emerging from quite different premises, even if the essential conditions for such development - action, perception and interpretation, in a continuous cycle of mutual reinforcement - are similar. Some children will take a longer period of time, others take less time, for example, to develop their stable linguistic system.

Having undergone a critical state, the system starts a new mode of behavior, which is called adaptivity. In the example of the salespeople, if one of them has a health problem that prevents him from selling for one day, he will have to rearrange his schedule so that it does not hinder him to achieve his final goal. We can observe that retroaction is strongly related to the fact that the system is open and adaptive, because as energy flows in and out, it adapts to the new conditions.

Baranger (2000) highlights that there is a special category of complex systems that comprises living beings. They are known as complex adaptive systems since they are capable of transformation to adapt themselves to a changing environment and, also, to modify the environment for their benefit. The proponent of this concept was John Holland, who defined complex adaptive systems as those "that have a large number of components, often called agents, that interact and adapt or learn" (HOLLAND, 2005, p. 1), "where the behavior of the whole is much more complex than the behavior of the parts" (HOLLAND, 1998, p. 2).

Holland (1995) postulates seven basic elements that characterize complex adaptive systems: four are properties: (1) aggregation: standard way 
of grouping what is in similar categories; (2) nonlinearity: interactions of elements makes the behavior of aggregates the product of these aggregates; (3) flows: network of nodes and links; (4) diversity: each agent occupies a niche that is defined by interactions centered on that agent; if the agent is removed, there is a cascade of adaptations, which generates perpetual novelty - and three are mechanisms: (5) tagging: underlie the hierarchical organization and define the boundaries; (6) internal models: agents select among input patterns and thus can anticipate the consequences of their choices; and (7) building blocks: parts that comprise the system, which can be used and reused in a variety of combinations.

Larsen-Freeman (1997) also points to some characteristics of what she calls a complex system: dynamism, nonlinearity, unpredictability, sensitivity to initial conditions, openness, self-organization, feedback sensitivity and adaptability. Complex systems change over time, and there is no way to determine exactly how these changes will happen. These changes are influenced not only by the initial conditions in which they arise, but also because the complex adaptive systems adjust when they receive feedback. Since these systems are open to new materials and energies, they absorb energy from the environment and increase their order and complexity while evolving. The changes that happen naturally and automatically in the systems can be defined by the process of self-organization. The elements rearrange themselves with each other and their interfaces so as to better achieve the aims of the system.

Following the premises of the Complexity Paradigm, Paiva (2010) underscores the importance of a concept used by the ecological perspective which can be very useful to Applied Linguistics: affordances. Miller (2009) also explains that this concept is useful to reflect upon the possibilities and constraints of a communication means, as for instance, digital artifacts.

The term affordance, coined by Gibson (1986), is explained as:

The affordance of the environment are what it offers the animal, what it provides or furnishes, either for good or ill. The verb to afford is found in the dictionary, but the noun affordance is not. I have made it up. I mean by it something that refers to both the environment and the animal in a way that no existing term does. It implies the complementarity of the animal and the environment (GIBSON, 1986, p. 127).

Understanding the complexity of the perceiving process, Norman (2004) reminds us affordances are a natural part of the environment and do not need to be visible, known or desired. According to him, some affordances are yet to be known and, we may not even know all the affordances of everyday objects. 
Van Lier (2004) offers three advantages to use the concept of affordances in the field of Applied Linguistics, specifically when observing the process of language learning. First, because this view assumes that an active learner establishes relationships with and within the environment. Secondly, this approach accommodates the rich complexity of environmental factors, including the student physically, socially and mentally. Finally, it assumes that properties of the environment can influence the learner as he realizes and acts upon the environment.

For this research, it is interesting to comprehend that affordances serve to enable and to constrain actions in the virtual environment. Churchill (2007) suggests that when an individual is situated in a context, he is necessarily focused on what surrounds him. It is important to notice that most contexts with which we interact are produced by human beings themselves, and thus they presuppose trends for interaction in these contexts. Hence, the relationship between individual and environment favors certain types of interpretation and action, while disfavoring other types. In order to illustrate the concept of affordances, he refers to Internet pages: "[...] drop-down menus common to many forms of text software afford operations listed in their menus, but also constrain the range of possible actions" (p. 341).

Norman (2004) names this process of interpretation as "perceived affordances". Young, Barab and Garret (2000) claim that it is necessary to understand there is a difference between what is possible and what is interpreted. Detecting the affordances of the environment may be done differently. For instance, it would be a limitation when one does not have wide opportunity of engaging and acting in this environment. The authors propose the term effectivities: while affordances may be limited to the properties of the environment that enable action and that are specified in the context, effectivities are related to the capabilities of the individuals to act upon the same context. To illustrate, stairs provide affordances for an individual to climb, but only if he possesses effectivities to complete this action; which would not happen if he were stuck in a wheelchair, for example.

It is necessary to clarify that the conceptions presented are directly related to the Complexity Paradigm. When we analyze affordances and effectivities, we are not dealing with possibilities of cause and effect; which means, there is no single affordance for a single effectivity. In the relationship between agent and environment, what we have is a complex adaptive system, marked by different nested levels, which combine within the system. Founded on the ecological theory, which I defend is in tune with the Complexity Paradigm, Young, Barab 
and Garrett (2000) have elaborated a figure to demonstrate the nested couplings in a learning system, whose example could be interactive technology. I present FIG. 1, and after describing it, I denote some limitations which will be reviewed in 11the light of the Complexity Paradigm:

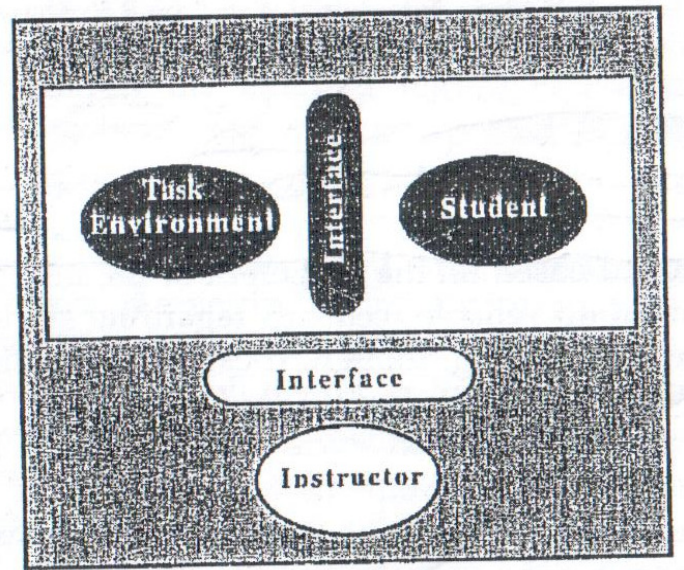

\section{Tintefrete}

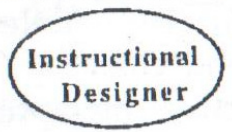

FIGURE 1 - Levels of affordances and effectivities in an agent-environment interaction Source: Young, Barab, Garrrett, 2000, p. 156

At the top of the figure, we can observe the student nested within the learning situation (agent-environment interaction). The adoption of a task would initiate the process of student interaction with the learning situation, and this would lead him to take the expected learning trajectory. At the intermediate level, the system is coupled with the instructor-student environment. Due to this connection, the instructor can either detect disturbances - e.g. diversion of previously set of instructional objectives - or initiate corrective actions, whether in form of suggestions or questions; thus, collaborating with the given task. At the bottom of the figure, there is an instructional designer, who can be coupled with the student-environmentteacher system and can evaluate the trajectories generated by the learning situation. This instructional designer can detect disturbances, e.g. not-achieved goals, and if necessary, change the design to minimize or interrupt the difficulties encountered in this situation. 
I believe this process is not as linear as defended by Young, Barab and Garrett (2000), and that the coupling process contains more connections than the tripartite proposal presented. One of the situations that would invalidate this linear proposal would be the fact the teacher and the instructional designer are the same person, playing these roles simultaneously. This would lead to the double role of detecting different disturbances and acting on distinctive levels, with the goal of solving possible difficulties. Furthermore, it is possible that the student himself can detect disturbances and solve them, using the affordances of the virtual environment.

\section{Methodology}

This is a descriptive research of qualitative nature and of virtual ethnographic orientation (HINE, 2000) about VLEs. In researches about online environments, Hine (2000) defends that the Internet should be considered, at the same time, as a discursive culture and as a cultural artifact, which, in any way, implies textual materiality. It is important to focus on the context in which a technology was used and ask if this context shapes its uses and effects since "the properties of the Internet are differentially socially constructed in the multiple social settings that develop online" (HINE, 2000, p. 20).

The courses offered for the generation of data were two undergraduate online disciplines entitled "Digital Literacy". The syllabi of both disciplines, located in the area of Applied Linguistics, had the goals of introducing students to digital literacy through the use of computerized tools, of engaging them in the production of digital genres and in the reflection on the use of tools provided by the computer and the Internet in the teaching and learning process.

Two VLEs were (re)configured for the disciplines, one from the platform TelEduc (second half of 2007) and another from the platform Moodle (second half 2008). The participants were an audience of 52 students (26 each semester) enrolled in the Languages and Literature Teaching degree at the Federal University of Minas Gerais (henceforth UFMG). Three professors also participated in it - I was one of them and acted as a teacher-researcher.

In order to demonstrate that VLEs are complex adaptive systems, I observed the system at the end of the courses, when it comes to an attracting ${ }^{2}$

\footnotetext{
${ }^{2}$ Larsen-Freeman and Cameron (2008, p. 50) define attractor as "a region of a system's state space into which the system tends to move".
} 
state called fixed, stable or profound; which means that the system can be considered "dead" since there is no further interaction. Still, it is possible to analyze the flow and dynamics of the system while it was in use, by browsing through different tools and reading the texts produced.

The methodological procedures of the research were: 1) Teaching of two courses using different online platforms, during one semester each, for the generation of data; 2) Register of all interactions of each VLE; and 3) Use of data from participants for analysis. As for analysis procedures, I began examining the genres within their contexts as proposed by Askehave and Swales (2001) by identifying the online discourse communities, ${ }^{3}$ their values, objects, rhythms, expectations and repertoire of genres, and after repurposing the genres, by identifying their characteristics.

\section{Discussion}

An important aspect of the establishment of a VLE which I mention in this paper concerns the characteristics of the VLE's interface. While acting upon different affordances provided by the platforms TelEduc and Moodle, I realized how the work of the teachers as online designers is configured to realize, throughout the process, the affordances that fit the best way possible to their educational goals. Let me use the genre "journal" as an example: since it was not possible for the students to respond to the teacher's comments in the "journal" tool, they used the forum tool for that purpose; therefore, the forum occupied a new niche. This example illustrates how a specific platform may lead to a particular effectivity.

To begin my reflections, I present a brief analysis of the surveys conducted in both VLEs, noting the differences in relation to affordances. It is important to point out that there was an expectation of little variability, due to the fact that the survey may be considered a more ritualized genre (MAINGUENEAU, 1999, 2004), i.e., its own structure of question and answers in multiple choice style leaves little open variation. Regarding the format, the surveys both in TelEduc and in Moodle departed from the same initial conditions. The teacher posted the question

\footnotetext{
${ }^{3}$ Although Askehave and Swales (2001) use the term "discourse community", I extend it to "online discourse community" due to the context in which this research was carried out. The concept of "discourse community" is explained by Swales (1990) as a social group whose members have similar goals and who use communication in order to achieve them.
} 
and options as registered in the following excerpt and selected a date to start and end the participation of learners:

\section{Excerpt \# 1:}

How would you evaluate your own level of digital literacy?

1) I have difficulty when using the computer and the Internet.

2) I can just do the basic stuff (typing, e-mail, browsing).

3) I use with little difficulty some tools of the computer and the Internet.

4) I can easily use various tools of the computer and the Internet.

5) I can be considered an expert.

The reports with results were similar although they showed some variations. Both TelEduc and Moodle offer lists of participants, option chosen by the student (individually) and how many votes each option received. TelEduc presents the results in numbers and percentages, whereas Moodle does it in numbers and displays them on a chart, as shown in FIG. 2. Moodle also offers photos of participants and their choices distributed in a graph.

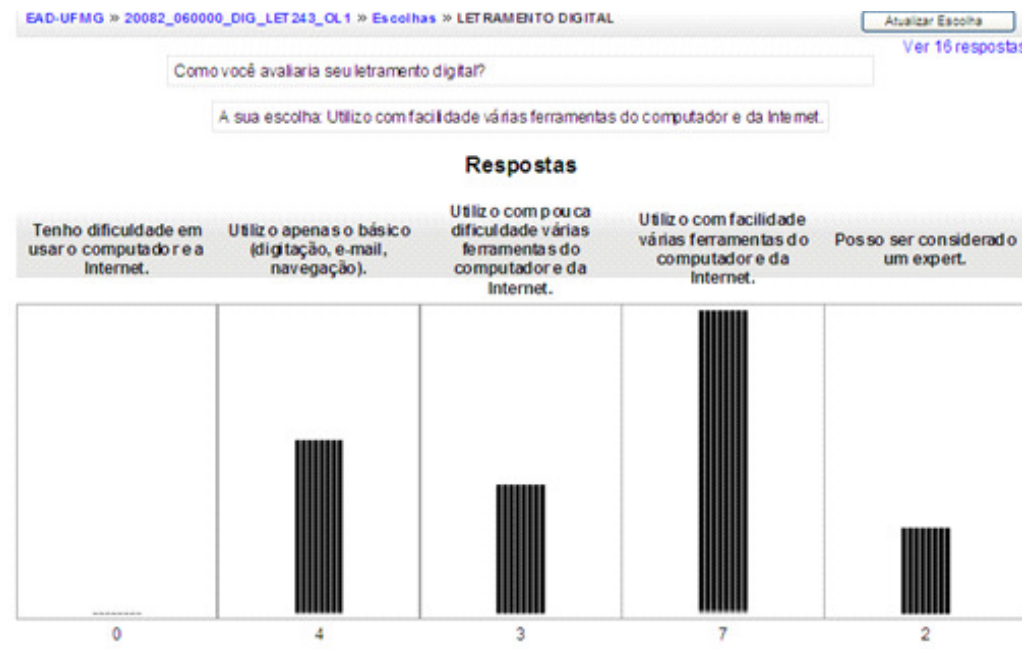

FIGURE 2 - Report on participation in survey on Moodle $^{4}$

${ }^{4}$ Since the disciplines were conducted in Portuguese, some of the figures will display some information in Portuguese. I will use footnotes in order to offer a brief explanation. FIG. 2 shows the answers to the survey which can be read in Excerpt \# 1 . 
When using the survey tool in both TelEduc and Moodle, the instructional goal remained the same, i.e. to know the views of learners on their own level of digital literacy in order to better monitor their individual progress. I emphasize, however, that there was diversity (HOLLAND, 1995) from the affordances provided. Firstly, due to the unpredictability of events in the course of each discipline and the progressive establishment of the VLE, it was necessary to make some adjustments, such as the proposal of an extra survey in TelEduc and two surveys in Moodle, as I will explain below.

The very structure of the activity survey, both on TelEduc and on Moodle, occurred according to the affordances provided and the very process of evolution of the disciplines, which was permeated by unpredictability. On TelEduc, it was necessary to set up two surveys, as explained by me in an email sent to all participants of the course and reproduced in excerpt \# 2:

\section{Excerpt \# 2:}

New survey. Because of a problem in the configuration of the environment, it will be necessary to reanswer the survey this week. Please, reply to it again, even if you did it last week. Your new deadline will be Saturday evening.

Posted on TelEduc on August 13, 2007.

When configuring the first survey, two of my choices, which can be seen in FIG. 3, prevented me from achieving my instructional goal. By choosing not to select which results were going to be shared with the teachers was the reason why they were not displayed at all. Besides, opting for the non-identity of the votes restrained me from knowing the opinion of each learner, invalidating the idea that the survey would be used to better understand the participants. Thus, it was necessary to redesign it by correcting the identified errors, which consequently demanded new participation of the learners.

\begin{tabular}{|ll|}
\hline Configurações & \\
\hline Aplicação & Alunos \\
Compartilhamento de Resultado & \\
Resultado parcial & Sim \\
Identidade dos votos & Não \\
Número de escolhas & Somente uma alternativa \\
\hline
\end{tabular}

FIGURE 3 - Interface of survey design on TelEduc ${ }^{5}$

\footnotetext{
${ }^{5}$ FIG. 3 reads: Line 1 - Application - Students; Line 2 - Sharing results; Line 3 Partial results - Yes; Line 4 - Identity of votes - No; Line 5 - Number of choices - Only one alternative.
} 
As for Moodle, the results of learners' perceptions in relation to their digital literacy needed to be drawn from two identical surveys, in different environments, though. Due to a restructuring of the curriculum of the Languages and Literature Teaching degree at UFMG, participants of the course "Digital Literacy 2008-2" were enrolled in two classes: LET 175 and LET 243 , which resulted in two different interfaces to the same class. Until enrolled students could be informed about the use just of the interface LET 243 only, it was necessary to keep both interfaces running during the first two course weeks, which resulted in two separate surveys.

Another interesting aspect observed was that the tagging mechanism (HOLLAND, 1995), on TelEduc, is the term Survey, while on Moodle it is an icon (a question mark) and the term Choice. When either the link Survey or Choice is selected, the genre is tagged by its format: question and options of answers on both VLEs. According to the Cambridge Online Dictionary, "survey" is defined as "a set of questions people are asked to gather information or find out their opinions, or the information gathered by asking many people the same questions". 6 The term Choice, used on Moodle, is defined by the same dictionary as "an act of choosing, decision". ' I believe this term does not clarify so well the genre "survey"; however, the fact there is a question mark (?) before the term Choice already leads to an internal model (HOLLAND, 1995) for the VLE user, who will better understand the tool by the structure of the activity to be completed (questions and options). As stated in Miller (2009), it is necessary to observe the affordances to understand the possibilities and constraints of a specific technological artifact. I contend, however, that the most interesting is the perception itself, because the user of this artifact tends to find its better trajectory, what can contribute for the achievement of his goal or the understanding of an interface. In this example, a process marked by a question mark.

It is important to underline that there is a difference between what is possible and what is interpreted (YOUNG; BARAB; GARRET, 2000), which is not always predicted by all the participants of a given process. Two relevant events occurred when the members of the online discourse community of 2007-2 were introducing themselves on TelEduc. First of all, a forum thread

\footnotetext{
${ }^{6}$ Available at: <http://dictionary.cambridge.org/dictionary/american-english/ survey_1?q=survey>.

7 Available at: <http://dictionary.cambridge.org/dictionary/american-english/ choice_1?q=choice $>$.
} 
opened at the same week of the self-presentation "competed" against the assignment of writing their profiles. When designing both assignments, I provided affordances that have resulted in imprecisions related to my instructions. Initially, I posted the text transcribed in excerpt \# 3 below, in order to guide our weekly discussions, which had as a main goal to familiarize students with the platform TelEduc:

\section{Excerpt \# 3:}

Welcome!

As specified in the link Course Dynamics, we will use this week to get used to TelEduc and to interact so we can get to know each other better. Let's use this forum to exchange ideas about who we are and what we expect from the discipline; besides, to ask questions, especially after carefully reading the link Environment Structure. It's your turn!

Posted on TelEduc on August 6, 2007.

Some excerpts of my initial comment in the forum - such as "we can get to know each other better" and "about who we are" - may indicate an invitation to a self-introduction, such as the ones they did in the link Profile, or what all of them should have done since this was part of the assignments for the first week. Nevertheless, I believe that the message reproduced in excerpt \# 4, the second post mentioned in the forum, may have contributed to trigger a series of posts that mingled with what was proposed as a task for the link Profile. This validates the idea that the initial conditions influence but do not determine the trajectory of a complex adaptive system, because it is open and new energy flows into and out of it, helping to modify the route:

\section{Excerpt \# 4:}

Hello everyone!

My name is Lívia. ${ }^{8}$ I'm a student of the extension program and I'm in my last semester. I have already taken two online courses during my undergraduate experience and I decided to enroll in another because the previous experiences were enriching. I intend to dedicate as much time as I can to this course because I am very interested in the subject. I hope we have a great semester! A Hug...

Posted on TelEduc on August 7, 2007.

\footnotetext{
${ }^{8}$ As stated in the research project, approved by the Ethic Committee, in order to preserve the identities of the participants, all the names have been modified.
} 
It is interesting to point out that the author of the message above has not completed the task of filling in her profile during the week she was supposed to and that she just did it (adding other personal information) later. This indicates that, not seeing the tool Profile as the appropriate niche to post her introduction, she perceived affordances in another channel which was available to perform a discursive practice that is common at the beginning of any course: a self-introduction. I believe that I have provided openness in my original text by not indicating that there was specific space in which introductions were being posted. This may have led other learners to see the forum as a proper space to post their personal introductions.

To illustrate what happened, I will use a student's post in the forum. By checking the heading and the format found in Profile, it was evident that this student used only the resource "copy and paste" to insert her post in the forum. It seems she was trying to find the easiest way to complete both assignments given during the first week (see FIG. 4, as follows):

\section{Apresentação}

Candice Maria da Silva

Email: candicemarias@yahoo.com.br

Função: aluno.

(Foto Não Disponível)

Estou no quinto período do Curso de letras e minha Habilitação é licenciatura em inglês. Eu faço um estágio no Núcleo de estudos canadenses e gosto muito de coisas relacionados com o Canadá. Eu me interesso muito pela área de linguística Aplicada. Na verdade, eu me interesso por tanta coisa, tudo que eu vejo de novo eu me interesso. Por isso que decidi fazer essa disciplina letramento digital, acredito que vai me ajudar o conhecer mais do mundo digital.

Um abraço a todos.

Candice

FIGURE 4-Student's personal introduction posted on her Profile on TelEduc ${ }^{9}$

Recurring patterns as the one described have led me to understand the proposed tasks as motivating learners' participation. Nevertheless, this motivation has not always been accompanied by concern with the quality of participation, only a way of alignment to the demands of the discipline.

\footnotetext{
9 This message will not be translated because it was used just to illustrate it was an identical self-introduction in both links.
} 
Candice had to complete the tasks of participation in the links forum and Profile and it seems she found a way to accomplish both tasks by posting one text only.

It is necessary to reflect if the discursive interrelationship between the Profile and the forum also happened in the discipline 2008-2 on Moodle since there was interaction among participants in the forum entitled "Studying online: our first contact". The following excerpt (excerpt \# 5) demonstrates the initial conditions of the proposal of the teacher when opening the forum, which happened concurrently in the same week when they had to fill in the Profile:

\section{Excerpt \# 5:}

This is our first contact and you will have this week to get used to the virtual environment so the "Reading assignments" will be very simple. Watch the video Pela Internet by Gilberto Gil and read the short story The Book of Sand by Borges so you can be informed during our initial discussion. What do you think of the Internet? What are the advantages and disadvantages it brings to our discipline? What do you expect from our online course?

I am anxious to read about you both in the Profile and in the Forum.

Cheers!

Initial message posted by teacher to guide the first week Forum.

It seems to me that as explicit as the ideas posted in the texts "first contact" and "initial discussion" have been, other textual elements made it clear that the focus of the discussion was the discipline itself and the learners' expectations towards it. Thus, there was no occurrence of self-introduction on the first forum on the Moodle platform, and references to personal characteristics always had a relation to the main topics of the discipline. This indicates, at first, that the initial conditions influence the trajectories of a system even though they do not determine them, and, still, that the affordances which are more clearly provided tend to trigger reactions which are closer to what is expected, in this case, by the teachers.

The process of perceiving affordances is clearly complex, as already claimed by Norman (2004). I illustrate this with the fact that Moodle is marked by graphical representations of the participants, who may upload their photos (or any other images that may represent them) in the link Profile, and these photos will accompany all of the participants' comments in other building blocks of the VLE. On the platform TelEduc, this does not happen. The platform allows you to upload a photo/image to the participant's profile, but it does not import this photo/image to other building blocks. Interestingly, I noticed that this causal 
relationship does not hold true when it comes to complex adaptive systems. In one of the chats conducted in the 12th week of the course of the class of 20072 , on the platform TelEduc, one of the students writes about her classmate referring to the graphical representation he made of himself with the comment (excerpt \# 6) shown below:

Excerpt \# 6:

... yeah, that's right... where is Mauro Simpson, guys...

Excerpt from chat interactions on October 302007.

The student had produced an avatar in a website of the Simpsons, ${ }^{10}$ instead of uploading a photo. In the student's words: "Because it is not possible to put icons in the profile and as I still haven't taken a picture of myself, I created an avatar in the site of the Simpsons movie and uploaded it here. I don't know if that'll be much of a help!". The graphic representation of a Simpson avatar was only visible in his Profile, and, nonetheless, it was perceived by a classmate and retrieved in a later comment. This shows us that the set of self-introductions posted in the link Profile emerged as a reference list to inform the interactions among the participants and that the affordances of this list were remarked in an improbable or unexpected way, which endorses the unpredictability of complex systems.

The unpredictability of the perception of affordances also triggered some disturbances in the system when the participants did not take into consideration some actions which would be appropriate. The link Forum, for example, was recurrently used on both the TelEduc and the Moodle VLEs as a resource of interaction even when the student felt that it was not an appropriate link for a particular post. I illustrate with an exchange of interactions between a student and me - the teacher (together in Excerpt \# 7). In order to contextualize, on the previous Sunday (August 12, 2007), I had opened a discussion thread with a quote by Pierre Lévy and a series of questions that could guide the students to reflect upon the subject and share their opinions. Instead of getting an "academic response", you will notice I received a demand to solve a technical problem.

${ }^{10}<$ http://simpsonizeme.com>. 


\section{Excerpt \# 7:}

Teacher, sorry to talk to you here without answering the questions you posted but I have no idea where I can talk directly to you.

I have two profiles in this discipline and I still could not access another discipline in which I am enrolled - LET 175 OL1.

Please exclude the profile which has no description.

Thank you.

\section{Lúcia Zanutim Moraes}

Student's reply to teacher's theoretical discussion posted on August 132007.

$\mathrm{Hi}$, everyone! In case this is a general doubt: in order to discuss any private subject let's use the E-MAIL of the TelEduc environment. Lúcia, we are already arranging the exclusion of your second profile.

\section{Hugs}

Teacher's reply to Lúcia’s comment on August 132007.

The non-perception of the affordances of the environment, as expected, resulted in the need for renegotiations between teachers and learners and, sometimes, dissatisfaction on the part of learners, which I illustrate with excerpt \# 8. Curiously, this message was posted on the VLE TelEduc which provides a list of available tools with explanations of their use in the link Environment Structure, and not the one on Moodle that does not offer such explanations. Once again, this points to the unpredictability of complex adaptive systems. It seems to me that the trajectory of the posts that did not meet the expectations of the learner, named Bruna, proved to be a disturbing element of the system:

\section{Excerpt \# 8:}

Teachers,

I have noticed some posts in inappropriate places, which causes a little mess and disorganization... Don't you believe it is convenient for you to send a general e-mail alerting students about it, explaining what should be posted in each item of the menu? I have already talked to the ones closer to me, but I don't know if this person did not understand or what...

Hugs, Bruna

Message sent, via e-mail, by student, on August 302007. 
I offer another example of how the non-perception of certain affordances can disturb the system's evolution. As it can be noticed in the following interactions (collected in excerpt \# 9), the greetings and the first reactions to a chat activity in the online discourse community which emerged at the discipline "Digital Literacy 2007-2" were disturbed due to technical specification of the platform TelEduc I was unaware of. The specification was that there is only one chat room for all sessions. When students from Group 3 began to enter the room, those from Group 6 were still discussing the theme of the forum, and I was trying to find a solution so that both groups could interact simultaneously in different spaces:

Excerpt \# 9:

(15:05:16) Candice Enters the chat room...

(15:05:23) Cristina Enters the chat room...

(15:05:49) Márcia tells Everyone: I think we gotta get out for the other group to get in

(15:05:56) Cristina tells Candice: was waiting!!!

(15:06:01) Bruna tells Everyone: gosh it seems there's just one chat room. The guys from the other group are coming in

(15:06:11) Candice tells Everyone: and I was waiting for you

(15:06:18) Sueli tells Everyone: That's it. How about discussing this by e-mail?

(15:06:30) Bruna tells Everyone: but it seems the teacher went to another room

(15:06:32) Carla tells Everyone: We can discuss in the forum.

(15:06:39) Candice tells Cristina: ops

(15:06:39) Amanda tells Everyone: ok

(15:06:42) Cristina tells Candice: where's everyone

Another interesting point to mention is how the affordances are perceived and used in favor of the participants of an online discourse community, be they students or teachers. In the next example, I understand that although TelEduc does not offer two separate spaces for receivers, so that one of them is CarbonCopy, many times, the intention of the teachers was to use this resource. Although the message below has not been addressed to one of the groups of receivers ("All the teachers"), according to the vocative which precedes the message, it was necessary that the teaching group were aware of 
the message. The exchange of a member of one of the groups generated changes in the whole assignment process; thus, it was necessary that all teachers were informed of the new group formation, which explains why "All the teachers" worked as CarbonCopy.

\begin{tabular}{l}
$\begin{array}{l}\text { Sender } \\
\begin{array}{l}\text { Teacher } \\
\text { All the teachers } \\
\text { Group 6 }\end{array}\end{array}$ \\
$\begin{array}{l}\text { Subject } \\
\text { new participant }\end{array}$ \\
$\begin{array}{ll}\text { Message } \\
\text { Hi everyone from group 6, } \\
\text { You have just gotten another classmate in your group. It is Lúcia. I hope she gets a warm welcome. }\end{array}$ \\
\hline
\end{tabular}

FIGURE 5 - Message sent by teacher via E-mail on TelEduc

Regarding the effectivities of affordances in favor of the students, I also noticed some instances of e-mail use when learners faced difficulties when posting tasks in other areas of VLEs. As it can be read in the following message, there was use of the message space of the e-mail message to post the activity, when a learner faced problems when attaching files to messages, as proposed in week 3 activity on the TelEduc VLE. The e-mail was used to replace other tools available in VLE every time learners found limitations of digital knowledge to perform their tasks, as it can be seen in the following example (excerpt \# 10):

Excerpt \# 10:

I can't send as an attachment.

There goes a copy of the file:

Rodrigo Graciliano Monteiro Rios - rodrigogmrios@yahoo.com.br Internet Browsing Assignment sent by E-mail on August 252007.

On the Moodle VLE, the system guarantees that private messages were automatically forwarded to the private e-mail (external to the system) of the participant, and the same happened with the messages posted on the forum. These messages were marked by a note copied in FIG. 6:

This e-mail is a copy of a message sent to you at "EAD-UFMG"

FIGURE 6 - Excerpt of automatic messages sent from Moodle to private $e$-mail 
To reply to messages, I did not resort to Moodle, but answered directly from my private e-mail, addressing the message to the external participant. This was an effectivity of the affordances in my favor, simplifying a process that would make me go through several windows to complete. In a way, I can point out that the affordances provided by the Moodle platform greatly influenced the diversity of uses of the genre e-mail ${ }^{11}$ and, hence, the choice of other processes, due to the limitations imposed on the platform for the typical use of the e-mail in a VLE.

The e-mail messages, both on TelEduc and on Moodle, aggregated in a particular link, and, unlike other links, such as forums and chats, what was aggregated depended on who was accessing the VLE and how this user realized the affordances of the environment. FIG. 7 below illustrates the TelEduc e-mail in one of my message viewing choices. These are messages received by me, in the form of listing, sorted from the date they were sent, in reversechronological order, with the presentation of 25 (twenty five) messages per page. It is possible to observe that aggregation happens automatically from the settings of the TelEduc platform itself, but the VLE provides affordances that will be implemented by the user, who decides how he or she wants to generate different forms of data aggregation.

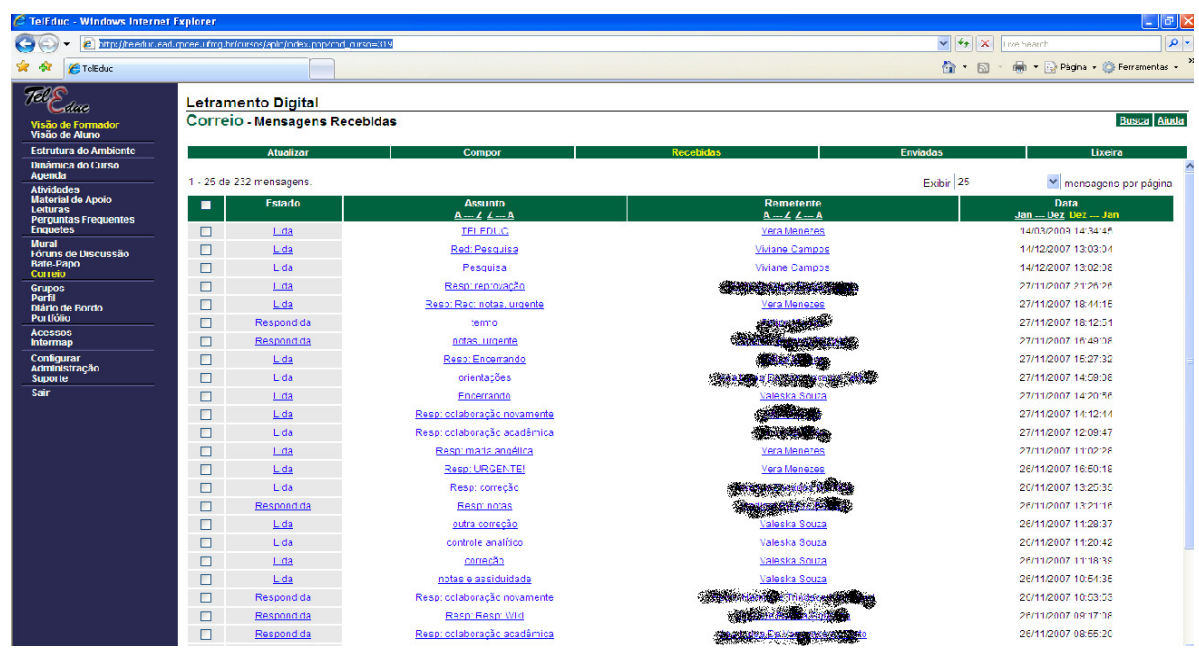

FIGURE 7 - Interface of the link E-mail on the platform TelEduc

${ }^{11}$ Although there has been heated discussions on the status of e-mail as a genre or not, I will opt to refer to it as a genre as it is listed in the genre dictionary by Costa (2008). 
As for internal models (HOLLAND, 1995), I could see the affordances of the VLE platforms helped to anticipate more appropriate spaces to post teaching instructions. On the TelEduc VLE, the tagging Activities and its definition given at the Environment Structure provided internal models to ensure this was the niche in which assignment instructions were posted. On the Moodle VLE, since it was possible to post in the homepage, the teachers used this space for an easier visualization.

In the final week of the course "Digital Literacy Moodle 2008-2", when posting students' grades, I used the homepage even though the link News Forum was the most common niche for this kind of interaction throughout the course (besides e-mail, at the beginning). The final post of the week, presented in full below (excerpt \# 11), is a farewell message and presentation of attendance and grade controls, to be checked by the learners:

\section{Excerpt \# 11:}

24 november -30 november

FINAL WEEK

Dear learners, my virtual friends!

For me it was a great pleasure to build knowledge with you during this semester. Keep in mind that I learned a lot from our interactions. I thank all the ones who have sent me the consent form (and, again, ask Dora, Adriano and Sabrina for this academic collaboration) and as soon as my thesis is finished, I will share it with you. You have my e-mail, so do not hesitate to get in touch if you need anything or if you want to share any news. The VLE will remain open for you to visit although we will not continue our interactions in it.

Below you will find the attendance and grade controls in an excel sheet.

I will wait for complaints until Friday, when I will transfer the data to the official control form.

A big hug

Attendance control

Grade control

Final Forum

Excerpt of homepage of the discipline Digital Literacy 2008-2 Moodle.

The example given previously shows the diversity found in the process of aggregation of interactions which are characterized as instructions and how 
the affordances provided by the platforms TelEduc and Moodle have influenced aggregation. On the VLE TelEduc, we have observed there was fragmented aggregation since the instructions were in different links (besides Activities). As for the VLE in Moodle, the aggregation of instructions was assembled in the homepage of the virtual environment. This differentiates it from TelEduc in terms of an easier way to visualize and to browse since by just accessing the link of the course, learners could see a list of all tasks.

Regardless of the possibilities and constraints offered by the platforms TelEduc and Moodle, I could attest equifinality when it comes to both VLEs. I sustain that equifinality is the trend towards a specific final state even from different initial conditions and after following distinct paths (BERTALANFFY, 1975). In spite of similarities in initial conditions (same topic, same teacher, same university), there were differences not only among initial states, but also among trajectories. Nevertheless, both VLEs reached a state of fixed attractor at the end and learners completed their digital literacy processes.

I illustrate the characteristic of equifinality with the fact that at the end of the process, the members of both communities have demonstrated their satisfaction with the online discipline and the platform used. This can be noticed in the following messages. Recalling that online discourse communities represent classrooms, and, according to Bazerman (2006), it is in the intersection of all the forces that a classroom happens, it seems to me that different forces and different paths enabled the conformation to similar classrooms:

\section{Excerpt \# 12:}

The course was very well conducted, in an organized and stimulating way, by the teachers. The activities were very interesting and the instructions were clear, with suggestions of texts and sites, which added relevant information. Besides, the VLE TelEduc provides a series of resources for the posting of assignments and for the interactions among course participants. [...]

Message posted by the learner Rodrigo, at the Final Journal, on Nov. 242007.

\section{Excerpt \# 13:}

I started the course believing I would "review" things I already knew. And that's what happened. However, I reviewed with different eyes, those of a teacher. Despite daily contact with computers, I hadn't reflected on how the machine and the web, associated or not, may improve the quality of a class. [...]

The VLE Moodle was perfect. All the possibilities of organization and communication worked very well. And, certainly, all worked so well also because 
of the excellent mediation of the Teacher. As I have mentioned in a Forum, design is very important, but not enough without a competent mediator.

Message posted by the learner Janaína, at the Final Journal, on Nov. 202008.

This contentment agrees with the reflection that the affordances of the platforms were effected along the course with the aim of contributing to the communicative and academic purposes of participants, and this probably influenced the fact that, even on different platforms, equifinality could be observed when both VLEs were analyzed.

\section{Conclusion}

In this paper, I have explained how members of both online discourse communities effected the affordances of the environment, aiming the achievement of their own academic and communicative purposes, and how this led to equifinality, in both complex adaptive systems analyzed. Firstly, I have defended that one of the most important roles of a teacher in the VLE was to perceive and act upon affordances, pursuing pedagogical goals. I demonstrated that many affordances were used by learners - some in an atypical way - having proposed teachers' instructions as motivators of this use. Still, I attested the processes of perception and non-perception of affordances were complex and, sometimes, led to system disturbances. I concluded that the analyzed VLEs displayed the characteristic of equifinality despite the possibilities and constraints offered by the platforms TelEduc and Moodle.

The conclusion that teachers and learners used the affordances to achieve their own goals and that they found unexpected trajectories to do so could mean for platform designers that there is no such a thing as a "perfect" platform because when it becomes a VLE, it will be a complex adaptive system. As mentioned above, the system is open - energies flow in and out thus, initial conditions influence, but do not determine their trajectories. As many nested layers of a VLE cooperate and compete simultaneously, it is necessary that the teacher be prepared to deal with the non-linearity of the processes which will "certainly" emerge during the establishment of the VLE. 


\section{References}

ASKEHAVE, I.; SWALES, J. Genre identification and communicative purpose: a problem and a possible solution. Applied Linguistics. Oxford University Press, v. 22, n. 2, p. 195-212, 2001.

BARANGER, M. Chaos, complexity and entropy: a physics talk for non-physicists. 2000. Available at: <http://plato.if.usp.br/ fmt0308d/baranger2004.pdf>. Retrieved May 212009.

BAZERMAN, C. Gênero, agência e escrita. Edited by Angela Paiva Dionísio and Judith Chambliss Hoffnagel. Translated and adapted by Judith Chambliss Hoffnagel. São Paulo: Cortez, 2006. 144 p.

BERTALANFFY, L. Teoria geral dos sistemas. 2. ed. Translated by Francisco M. Guimarães. Petrópolis: Vozes, 1975. 351 p.

COSTA, S. R. Dicionário de gêneros textuais. Belo Horizonte: Autêntica, 2008. $182 \mathrm{p}$.

CHURCHILL, Eton. A dynamic system account of learning from ecology to form relations. Applied Linguistics, Oxford University Press, v. 29, n. 3, p. 339-358, 2007.

DAVIS, B.; SUMARA, D. Complexity and education: inquiries into learning, teaching and research. New Jersey; London: Lawrence Erlbaum Associates, 2006. 202 p.

GIBSON, J. J. The theory of affordances. In: GIBSON, J. J. The ecological approach to visual perception. New Jersey; London: Lawrence Erlbaum Associates, 1986. p. 127-143.

HINE, C. Virtual ethnography. London: Thousand Oaks, CA; New Delhi: Sage, 2000. 179 p.

HOLLAND, J. Hidden order: how adaptation builds complexity. Reading, MA: Addison Wesley, 1995. 185 p.

HOLLAND, J. Emergence: from chaos to order. New York: Basic Books, 1998. $258 \mathrm{p}$.

HOLLAND, J. Studying complex adaptive systems. Journal of Systems Science and Complexity, Beijing, Springer, v. 19, n. 1, p. 1-8, 2005.

JOHNSON, Steven. Emergência: a vida integrada de formigas, cérebros, cidades e softwares. Translated by Maria Carmelita Pádua Dias. Rio de Janeiro: Jorge Zahar Editor, 2003. 231 p.

LARSEN-FREEMAN, D. Chaos/complexity science and second language acquisition. Applied Linguistics, v. 18, n. 2, p. 141-165, 1997. 
LARSEN-FREEMAN, D.; CAMERON, L. Complex systems and applied linguistics. Oxford: Oxford University Press, 2008. 287 p.

LEITE, M. S. A.; BORNIA, A. C.; COELHO, C. C. S. R. A contribuição da teoria da complexidade à modelagem de sistemas. 2004. (copy)

MAINGUENEAU, D. Ethos, scénographie, incorporation. In: AMOSSY, R. (Ed.). Images de soi dans le discours: la construction de l'ethos. Lausanne: Delachaux et Niestlé, 1999. p. 75-100.

MAINGUENEAU, D. Diversidade dos gêneros de discurso. In: MACHADO, I. L.; MELLO, R. (Ed.). Gêneros: reflexões em análise do discurso. Belo Horizonte: NAD/FALE/UFMG, 2004. p. 43-58.

MILLER, C. Estudos sobre gênero textual, agência e tecnologia. In: DIONÍSIO, A. P.; HOFFNAGEL, J. C. (Org.). Estudos sobre Gênero Textual, Agência e Tecnologia de Carolyn R. Miller. Recife: Universitária da UFPE, 2009. 232 p.

MORIN, E. $O$ método I: A natureza da natureza. Translated by Maria Gabriela de Bragança. Paris: Seuil, 1977. Available at: <http://pt.scribd.com/doc/ 7125193/Edgar-Morin-O-Metodo-I-A-Natureza-Da-Natureza $>$. Retrieved January 102011.

NORMAN, D. Affordances and design. 2004. Available at: <http:// www.liacs.nl/ - fverbeek/courses/hci/AffordancesandDesign.pdf>. Retrieved June 302007.

PAIVA, V. L. M. O. Affordances beyond the classroom. (in press) 2010. Available at: <http://www.veramenezes.com/beyond.pdf>. Retrieved January 272011. SWALES, J. Genre analysis: English in academic and research settings. Cambridge: Cambridge University Press, 1990. 260 p.

VAN LIER, L. The ecology and semiotics of language learning: a sociocultural perspective. Boston: Kluwer Academic Publishers, 2004. 248 p.

WALDROP, M. Complexity: the emerging science at the edge of order and chaos. New York: Simon and Schuster, 1992.

WEAVER, W. Science and complexity. American Scientist, v. 36, n. 1, p. 536, 1948. Available at: <http://www.ceptualinstitute.com/genre/weaver/weaver1947b.htm>. Retrieved August 302008.

YOUNG, M. F.; BARAB, S. A.; GARRET, S. Agent as detector: an ecological perspective on learning by perceiving-doing acting systems. In: JONASSEN, D. H.; LAND, S. M. (Ed.). Theoretical foundations of learning environments. Mahwah; London: Lawrence Erlbaum Associates, 2000. p. 147-171.

Recebido em 06/10/2012. Aprovado em 19/03/2013. 